\title{
A Global Trend: Privatization and Reform of Social Security Pension Plans
}

\author{
by W. G. Poortvliet and T.P. Laine ${ }^{1}$ \\ I advise you to go on living solely to enrage those who are paying your annuities.
}

Voltaire

It was just over ten years ago that Chile undertook to privatize its social security system. At the time, it seemed to many observers a daring and almost radical step, prompted by severe financial stress as well as a strong commitment to the workings of the private market. Yet Chile's experiment has been successful and now serves as a reference point for many of the privatizations that have been instituted or proposed in various parts of the world.

Among the many reasons given for privatizing social security systems, several can be identified as the most important. One - especially significant in some developing countries - is the increasingly perceived inability of governments to equitably and efficiently manage a public system while still delivering an acceptable level of benefits. Another major reason is the desire to develop an increased level of privatized funds to support capital markets and contribute to productivity improvements.

Perhaps the most pressing reason arises where the burden of financing government systems has become simply intolerable - a problem occurring with increasing frequency in many countries of the world. The contributing factors are many: aging populations and resulting decreases in the number of active workers supporting each retiree; increasing governmental budget deficits ; poor coverage compliance; lenient disability retirement provisions; and the politicizing of social systems resulting in insupportable increases in real benefit levels. In turn these factors often culminate in a realization that the increasing burden of financing social security programs is contributing to sluggish economic growth, decreasing productivity and lessened international competitiveness.

For all these reasons, in most industrialized countries and many developing ones, many experts expect a marked shift from state plans to private sector plans - whether through a full or partial privatization or through an increased reliance on private sector provision of

1 William G. Poortvliet is Chairman of MetLife International Holdings, Inc. and Executive Vice President of Metropolitan Life Insurance Company. Thomas P. Laine is Manager of the Actuarial Financial Management unit in MetLife's International Operations Department. A summary of this paper was presented at the 21st General Assembly of the Geneva Association, Stockholm, June 9-10, 1994. 
retirement income. In many countries, the shift has already begun. In fact, early in 1991, a conference held in Paris by the Organization for Economic Cooperation and Development (OECD), while considering the many implications of this shift - did not question that the shift was inevitable. ${ }^{2}$

This study presents an overview of the underlying issues and the steps that are being taken or are likely to be taken to address the problems and - in some cases, the opportunities - that are seen to be arising, with an emphasis on the role the private sector, insurance companies in particular, are likely to play in developing solutions. The principal focus is on retirement savings and income, which is perhaps the social security program most frequently expected to be privatized on a large and growing scale. Government retirement savings and income benefits are a very large part of total social welfare expenditures $-40 \%$ or more in many countries. Too, this is an area with which the private sector has had much experience and success.

The study has three main parts. First, an overview is given of the financing and other significant issues that privatization seeks to address. Second, there is a general discussion of potential solutions and some of the criticisms that have arisen in connection with privatization efforts so far. Third, there is a review of the actions that have already been taken in a number of countries. Following these three main sections, a brief summary is offered of the conclusions which may be reached.

\section{The underlying problem}

\section{Financing issues}

Financing issues that arise in connection with social security systems have three major aspects: demographic, budgetary and competitive. At the same time, certain competitive and social trends are limiting the contribution of employers and family - two sources of retirement income support that traditionally have supplemented government retirement benefits.

\section{Demographics}

The demographic issue has its roots in three general trends: declining fertility rates, increased life expectancies and the aging of earlier generations born when fertility rates were high (e.g. the post-World War II "baby boom" generation that has occurred in some countries). It seems almost a demographic axiom that as populations become wealthier, more industrialized and less agrarian, fertility rates decline, often even to below the "replacement" level of 2.1 children per woman (the rate at which population growth will eventually cease and below which populations will eventually decrease). Fertility rates are now below replacement levels in all Western European countries except Ireland. Worldwide, the more developed countries, with $22 \%$ of the earth's population, have an average fertility rate of 1.9 , while in the less developed countries, the average is 3.6 , or nearly double! Table $1 \mathrm{~A}$ gives fertility rates over the past 40 years and extending into the next century for various countries (also see Figure 1).

Recently, with birth control methods widely available and often promoted by such governments as China and India (which together have more than one-third of the world's

${ }^{2}$ Debbie Harrison, Pension Provision in the EC, Financial Times Business Information, London, 1992 , page 12. 


\section{Table 1A}

Total Fertility Rate (per woman)

\begin{tabular}{|c|c|c|c|}
\hline & $1950-1955$ & 1985-1990 & $2020-2025$ \\
\hline $\begin{array}{l}\text { North America } \\
\text { United States } \\
\text { Canada } \\
\text { Mexico } \\
\end{array}$ & $\begin{array}{l}3.45 \\
3.70 \\
6.75\end{array}$ & $\begin{array}{l}1.92 \\
1.70 \\
3.60\end{array}$ & $\begin{array}{l}1.80 \\
1.80 \\
2.03\end{array}$ \\
\hline $\begin{array}{l}\text { South America } \\
\text { Argentina } \\
\text { Brazil } \\
\text { Chile } \\
\text { Venezuela } \\
\end{array}$ & $\begin{array}{l}3.15 \\
6.15 \\
5.10 \\
6.46\end{array}$ & $\begin{array}{l}2.96 \\
3.20 \\
2.73 \\
3.45 \\
\end{array}$ & $\begin{array}{l}2.24 \\
2.00 \\
2.25 \\
2.12 \\
\end{array}$ \\
\hline $\begin{array}{l}\text { Europe } \\
\text { Austria } \\
\text { Belgium } \\
\text { Denmark } \\
\text { Finland } \\
\text { France } \\
\text { Germany } \\
\text { Greece } \\
\text { Hungary } \\
\text { Ireland } \\
\text { Italy } \\
\text { Luxembourg } \\
\text { Netherlands } \\
\text { Norway } \\
\text { Poland } \\
\text { Portugal } \\
\text { Spain } \\
\text { Sweden } \\
\text { Switzerland } \\
\text { Turkey } \\
\text { United Kingdom }\end{array}$ & $\begin{array}{l}2.09 \\
2.34 \\
2.53 \\
2.97 \\
2.73 \\
2.16 \\
2.29 \\
2.73 \\
3.37 \\
2.32 \\
1.97 \\
3.05 \\
2.60 \\
3.62 \\
3.05 \\
2.57 \\
2.21 \\
2.28 \\
6.85 \\
2.18\end{array}$ & $\begin{array}{l}1.45 \\
1.56 \\
1.54 \\
1.66 \\
1.82 \\
1.44 \\
1.53 \\
1.82 \\
2.28 \\
1.33 \\
1.47 \\
1.56 \\
1.80 \\
2.15 \\
1.60 \\
1.46 \\
1.91 \\
1.55 \\
3.79 \\
1.81\end{array}$ & $\begin{array}{l}1.70 \\
1.70 \\
1.70 \\
1.80 \\
1.85 \\
1.70 \\
1.90 \\
1.80 \\
2.10 \\
1.70 \\
1.70 \\
1.70 \\
1.80 \\
2.00 \\
1.90 \\
1.90 \\
1.80 \\
1.70 \\
2.10 \\
1.80\end{array}$ \\
\hline $\begin{array}{l}\text { Asia } \\
\text { China } \\
\text { Hong Kong } \\
\text { India } \\
\text { Indonesia } \\
\text { Japan } \\
\text { Korea, South } \\
\text { Singapore }\end{array}$ & $\begin{array}{l}6.24 \\
4.43 \\
5.97 \\
5.49 \\
2.75 \\
5.18 \\
6.41\end{array}$ & $\begin{array}{l}2.38 \\
1.36 \\
4.20 \\
3.48 \\
1.68 \\
1.73 \\
1.69\end{array}$ & $\begin{array}{l}1.85 \\
1.70 \\
2.10 \\
2.10 \\
1.85 \\
1.85 \\
1.85\end{array}$ \\
\hline $\begin{array}{l}\text { Other } \\
\text { Australia } \\
\text { New Zealand } \\
\text { South Africa } \\
\text { USSR (former) }\end{array}$ & $\begin{array}{l}3.18 \\
3.54 \\
6.51 \\
2.82\end{array}$ & $\begin{array}{l}1.86 \\
2.04 \\
4.38 \\
2.43\end{array}$ & $\begin{array}{l}1.90 \\
1.90 \\
2.38 \\
2.10\end{array}$ \\
\hline World & 5.00 & 3.43 & 2.36 \\
\hline
\end{tabular}

Source: World Population Prospects 1992 ed, UN publication 


\section{Figure 1}

\section{Total Fertility Rate}

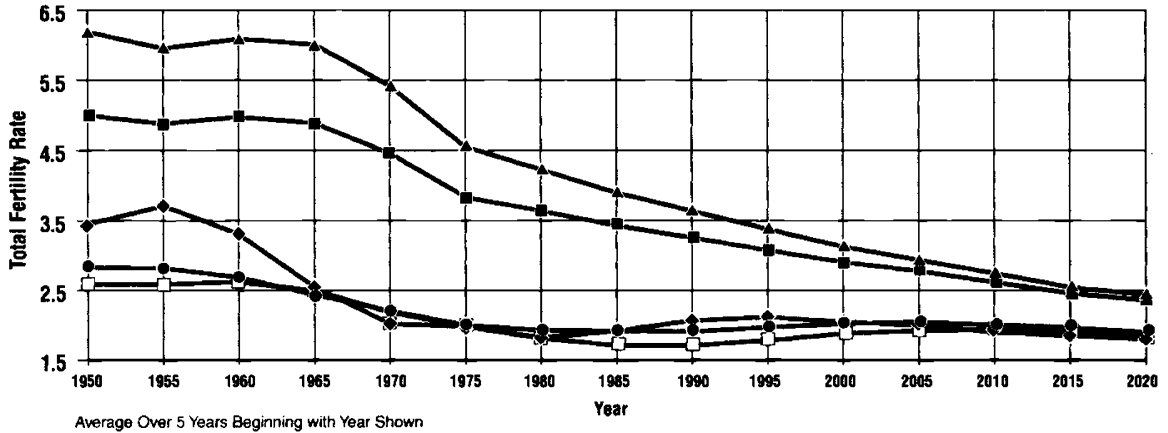

\section{Life Expectancy at Birth}

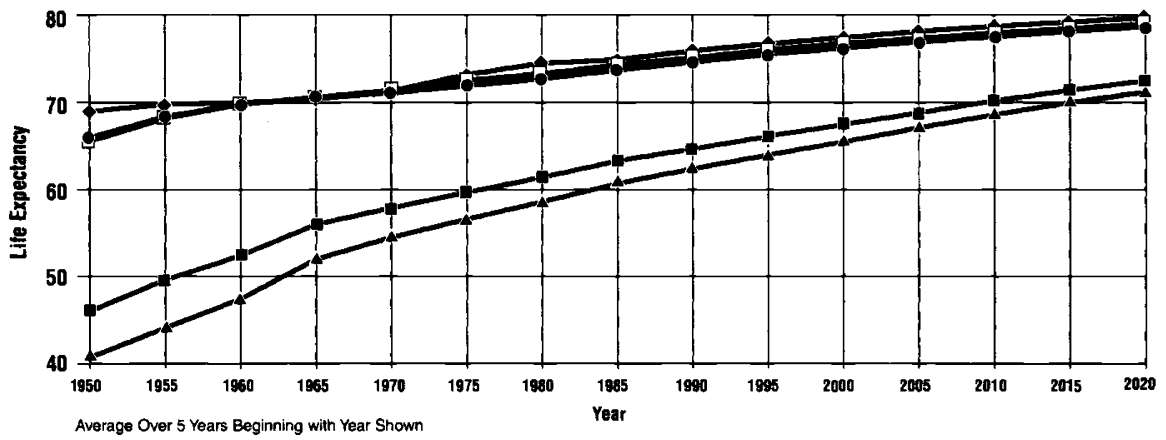

\section{Support Ratio}

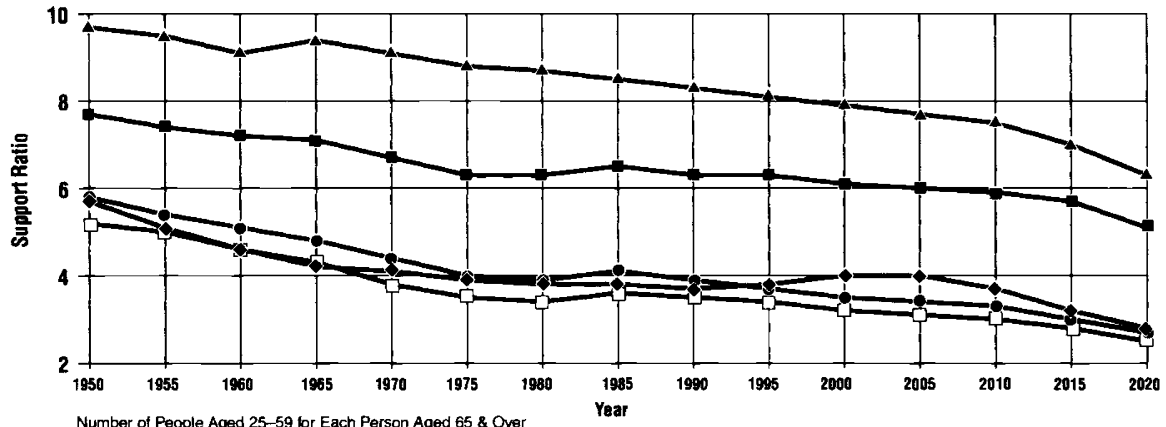

Number of People Aged 25-59 for Each Person Aged 65 \& Over

$$
\text { - World - Developed } \longrightarrow \text { Developing } \rightarrow-\text { USA } \square-\text { Europe }
$$


population) fertility rates are also beginning to decline in some of the less developed countries. For example, China's fertility is now 2.38 , half what it was only 15 years ago. The fertility rate in Singapore has dropped from 6.28 to 1.69 over the last 30 years and the population is aging so rapidly that Singapore has even adopted a pronatalist policy - tax rebates to encourage women to have three or more children - as a way of addressing aging and labor shortages. ${ }^{3}$

As a result of this trend, population growth rates have already begun to slow: over the period 1960 to 1990 , annual growth rates decreased from $0,86 \%$ to $0.32 \%$ in Europe, from $1.63 \%$ to $1.01 \%$ in Northern America, from $2.06 \%$ to $1.81 \%$ in Asia and from $2.75 \%$ to $1.87 \%$ in Latin America. As this deceleration continues, Europe is projected to be the first region to see the absolute level of its population actually begin to decline, beginning around the year 2020 .

At the same time, with medical and economic advances, life expectancies have improved. The worldwide average life expectancy at birth has increased from 46 in 1950 to 63 in 1990, an increase of 17 years! In the more developed countries, life expectancies increased from 66 to 74 over the same period, 11 years longer than the worldwide average. Thus there is room for further improvement in world life expectancies. Table 1 B gives life expectancies over the last forty years and extending into the next century (also see Figure 1).

As a consequence of these trends, the world's population is aging - and will age even more rapidly into the next century. The percentage of the world population that is over age 65 in 1990 was 6.2 , up from $5.3 \%$ in 1960 , and is increasing to $8.8 \%$ in 2020 .

For the more developed countries, the percentages of aged are much higher : $12 \%$ in 1990 and $16.8 \%$ in $2020 .{ }^{4}$ By 2020 , seven countries - Japan and six European countries, Denmark, Finland, Greece, Italy, Sweden and Switzerland - are projected to have $20 \%$ or more of their population over age 65 . Table 2 shows the aged percentage of the population for countries around the world for the years 1960, 1990 and 2020.

This is indeed a worrisome trend for the fiscal health of government social security systems, particularly since they are seldom pre-funded and almost invariably "pay-as-you-go" systems - under which current tax revenues are simply transferred to pay social security recipients. Thus, decreasing cohorts of working age people are being asked to support increasing cohorts of retirees, a trend with the obvious potential to cause increasing social and political concerns.

This factor is often measured by demographers in terms of "support ratios"; i.e., the ratio of the number of people of working age to the number of people above the ages at which retirement benefit eligibility generally begins. If it is assumed that the working ages are approximately 25 to 59 and that the age of government retirement benefit eligibility is 65 (though it is lower in some countries), the support ratios shown in Table 3 are obtained (also see Figure 1). The table shows these ratios for the OECD countries for the years 1960 ,

\footnotetext{
${ }^{3}$ Linda G. Martin, "Population Aging Policies in East Asia and the United States", Science, Vol. 251, February 1, 1991, page 527.

${ }^{4}$ For countries where the fertility rate is below the replacement level of 2.1 , these United Nations population projections are made assuming that the fertility rates will gradually rise towards 2.1 . Thus, if the fertility rates in the more developed countries - where fertility rates are generally under 2.1 either continue to decrease or remain the same, the aged percentage in 2020 would be even greater than the projected $16.8 \%$.
} 


\begin{tabular}{|c|c|c|c|}
\hline & $1950-1955$ & 1985-1990 & $2020-2025$ \\
\hline $\begin{array}{l}\text { North America } \\
\text { United States } \\
\text { Canada } \\
\text { Mexico }\end{array}$ & $\begin{array}{l}69.0 \\
69.1 \\
50.8\end{array}$ & $\begin{array}{l}74.9 \\
76.8 \\
68.8\end{array}$ & $\begin{array}{l}79.7 \\
80.7 \\
75.3\end{array}$ \\
\hline $\begin{array}{c}\text { South America } \\
\text { Argentina } \\
\text { Brazil } \\
\text { Chile } \\
\text { Venezuela } \\
\end{array}$ & $\begin{array}{l}62.5 \\
51.0 \\
53.7 \\
55.2 \\
\end{array}$ & $\begin{array}{l}70.6 \\
64.9 \\
71.5 \\
69.6 \\
\end{array}$ & $\begin{array}{l}74.1 \\
72.1 \\
74.6 \\
73.7 \\
\end{array}$ \\
\hline $\begin{array}{l}\text { Europe } \\
\text { Austria } \\
\text { Belgium } \\
\text { Denmark } \\
\text { Finland } \\
\text { France } \\
\text { Germany } \\
\text { Greece } \\
\text { Hungary } \\
\text { Ireland } \\
\text { Italy } \\
\text { Luxembourg } \\
\text { Netherlands } \\
\text { Norway } \\
\text { Poland } \\
\text { Portugal } \\
\text { Spain } \\
\text { Sweden } \\
\text { Switzerland } \\
\text { Turkey } \\
\text { United Kingdom }\end{array}$ & $\begin{array}{l}65.7 \\
67.5 \\
71.0 \\
66.3 \\
66.5 \\
67.5 \\
65.9 \\
63.9 \\
66.9 \\
66.0 \\
65.9 \\
72.1 \\
72.7 \\
61.3 \\
59.3 \\
63.9 \\
71.8 \\
69.2 \\
43.6 \\
69.2\end{array}$ & $\begin{array}{l}74.9 \\
75.1 \\
74.7 \\
74.6 \\
76.0 \\
74.8 \\
76.7 \\
69.5 \\
74.4 \\
76.3 \\
74.5 \\
76.8 \\
76.4 \\
71.7 \\
73.8 \\
77.0 \\
77.3 \\
77.4 \\
65.3 \\
75.0\end{array}$ & $\begin{array}{l}79.5 \\
79.6 \\
79.3 \\
79.4 \\
80.2 \\
79.5 \\
80.5 \\
75.5 \\
79.2 \\
80.3 \\
79.2 \\
80.5 \\
80.3 \\
76.3 \\
78.7 \\
80.5 \\
80.8 \\
80.8 \\
74.7 \\
79.7\end{array}$ \\
\hline $\begin{array}{l}\text { Asia } \\
\text { China } \\
\text { Hong Kong } \\
\text { India } \\
\text { Indonesia } \\
\text { Japan } \\
\text { Korea, South } \\
\text { Singapore }\end{array}$ & $\begin{array}{l}40.8 \\
61.0 \\
38.7 \\
37.5 \\
63.9 \\
47.5 \\
60.4\end{array}$ & $\begin{array}{l}69.4 \\
77.0 \\
57.9 \\
60.2 \\
78.3 \\
69.4 \\
73.5 \\
\end{array}$ & $\begin{array}{l}76.8 \\
80.5 \\
71.5 \\
72.6 \\
81.3 \\
76.7 \\
78.8\end{array}$ \\
\hline $\begin{array}{l}\text { Other } \\
\text { Australia } \\
\text { New Zealand } \\
\text { South Africa } \\
\text { USSR (former) }\end{array}$ & $\begin{array}{l}69.9 \\
69.6 \\
45.0 \\
64.1\end{array}$ & $\begin{array}{l}76.1 \\
74.5 \\
60.4 \\
69.1\end{array}$ & $\begin{array}{l}80.1 \\
79.4 \\
72.7 \\
75.5\end{array}$ \\
\hline World & 46.4 & 63.3 & 72.5 \\
\hline
\end{tabular}


Table 2

Percent of Population age 65+

\begin{tabular}{|c|c|c|c|}
\hline & 1960 & 1990 & 2020 \\
\hline $\begin{array}{l}\text { North America } \\
\text { United States } \\
\text { Canada } \\
\text { Mexico }\end{array}$ & $\begin{array}{l}5.3 \\
7.5 \\
4.1\end{array}$ & $\begin{array}{r}12.6 \\
11.5 \\
3.7\end{array}$ & $\begin{array}{r}16.3 \\
16.7 \\
7.2\end{array}$ \\
\hline $\begin{array}{l}\text { South America } \\
\text { Argentina } \\
\text { Brazil } \\
\text { Chile } \\
\text { Venezuela }\end{array}$ & $\begin{array}{l}5.5 \\
2.7 \\
4.7 \\
2.4\end{array}$ & $\begin{array}{l}9.1 \\
4.7 \\
6.0 \\
3.7\end{array}$ & $\begin{array}{r}11.0 \\
8.9 \\
9.6 \\
7.6\end{array}$ \\
\hline $\begin{array}{l}\text { Europe } \\
\text { Austria } \\
\text { Belgium } \\
\text { Denmark } \\
\text { Finland } \\
\text { France } \\
\text { Germany } \\
\text { Greece } \\
\text { Hungary } \\
\text { Ireland } \\
\text { Italy } \\
\text { Luxembourg } \\
\text { Netherlands } \\
\text { Norway } \\
\text { Poland } \\
\text { Portugal } \\
\text { Spain } \\
\text { Sweden } \\
\text { Switzerland } \\
\text { Turkey } \\
\text { United Kingdom }\end{array}$ & $\begin{array}{r}12.0 \\
11.5 \\
10.6 \\
7.2 \\
11.6 \\
11.5 \\
8.3 \\
9.0 \\
11.2 \\
9.3 \\
10.8 \\
9.0 \\
11.1 \\
5.8 \\
8.0 \\
8.2 \\
12.0 \\
10.1 \\
3.5 \\
11.7\end{array}$ & $\begin{array}{r}15.1 \\
14.9 \\
15.6 \\
13.3 \\
14.0 \\
14.6 \\
13.8 \\
13.2 \\
11.4 \\
14.1 \\
13.4 \\
12.7 \\
16.3 \\
10.0 \\
13.1 \\
13.4 \\
17.8 \\
15.0 \\
4.3 \\
15.7\end{array}$ & $\begin{array}{r}18.8 \\
19.7 \\
20.5 \\
20.7 \\
19.5 \\
19.1 \\
21.0 \\
16.8 \\
16.2 \\
20.9 \\
18.5 \\
18.1 \\
17.9 \\
14.4 \\
17.4 \\
18.4 \\
20.2 \\
20.2 \\
7.4 \\
18.2\end{array}$ \\
\hline $\begin{array}{l}\text { Asia } \\
\text { China } \\
\text { Hong Kong } \\
\text { India } \\
\text { Indonesia } \\
\text { Japan } \\
\text { Korea, South } \\
\text { Singapore }\end{array}$ & $\begin{array}{l}4.8 \\
2.8 \\
3.4 \\
3.3 \\
8.9 \\
3.3 \\
2.1\end{array}$ & $\begin{array}{r}5.7 \\
8.8 \\
4.5 \\
3.9 \\
11.7 \\
4.8 \\
5.7\end{array}$ & $\begin{array}{r}11.1 \\
18.0 \\
7.4 \\
7.8 \\
24.2 \\
11.9 \\
15.4\end{array}$ \\
\hline $\begin{array}{l}\text { Other } \\
\text { Australia } \\
\text { New Zealand } \\
\text { South Africa } \\
\text { USSR (former) }\end{array}$ & $\begin{array}{l}8.5 \\
8.6 \\
3.9 \\
6.7\end{array}$ & $\begin{array}{r}11.2 \\
10.8 \\
3.9 \\
9.3\end{array}$ & $\begin{array}{r}15.2 \\
14.6 \\
6.0 \\
12.5\end{array}$ \\
\hline World & 5.3 & 6.2 & 8.8 \\
\hline
\end{tabular}

Source: World Population Prospects 1992 ed, UN publication 
1990 and projected 2020 . The OECD average support ratio drops dramatically, from 5.0 in 1960 to 3.8 in 1990 to only 2.7 in 2020 . The decline in support ratios for Japan is especially striking - in 1960, its support ratio was the highest in any OECD country except for Turkey - and by 2020 its support ratio is the lowest of any OECD country. ${ }^{5}$

\section{Table 3 \\ Support Ratios \\ OECD Countries \\ Number of People Aged 25-59 for Each Person Aged 65 \& Over}

\begin{tabular}{l|c|c|c|} 
& $\mathbf{1 9 6 0}$ & $\mathbf{1 9 9 0}$ & $\mathbf{2 0 2 0}$ \\
\hline Canada & 5.5 & 4.2 & 2.7 \\
Japan & 7.4 & 4.2 & 1.8 \\
United States & 4.6 & 3.7 & 2.8 \\
\hline EU Countries & & & \\
Belgium & 3.9 & 3.2 & 2.3 \\
Denmark & 4.2 & 3.0 & 2.2 \\
France & 3.8 & 3.3 & 2.3 \\
Germany & 4.0 & 3.4 & 2.5 \\
Ireland & 3.5 & 3.6 & 2.6 \\
Italy & 5.0 & 3.3 & 2.2 \\
Netherlands & 4.7 & 3.8 & 2.5 \\
Portugal & 5.4 & 3.4 & 2.7 \\
Spain & 5.5 & 3.3 & 2.6 \\
United Kingdom & 4.0 & 2.9 & 2.5 \\
& & & \\
Australia & 5.1 & 4.1 & 3.7 \\
Austria & 3.8 & 4.1 & 3.0 \\
Finland & 6.0 & 3.7 & 2.1 \\
Hungary & 3.1 & 2.7 \\
Iceland & 4.9 & 3.6 & 3.0 \\
New Zealand & 4.2 & 3.1 \\
Norway & 4.7 & 2.1 & 2.5 \\
Poland & 4.0 & 3.7 & 3.1 \\
Sweden & 7.4 & 4.6 & 2.1 \\
Switzerland & 3.9 & 2.6 & 2.3 \\
Turkey & 4.6 & 3.3 & 6.4 \\
\hline Total OECD Countries** & 10.2 & 8.6 & 2.5 \\
\hline
\end{tabular}

"Luxembourg is not included.

*Arithmetic Average

Source: World Population Prospects 1992 ed, UN publication

5 When fertility rates are low, there are of course fewer children to be supported, a cost not reflected in these ratios. However the costs of supporting children is generally much less than for the elderly. Government benefits for the elderly in OECD countries are about three times that for children, on a per capita basis. 
For purposes of studying the impact on social security funding mechanism, a better measure (although not available on so wide a basis as support ratios) is worker to retiree ratios, which also bring employment trends into account. Support ratios overstate the possibility of support because they do not reflect the fact that many people of working age are not employed, whether because of unemployment, disability or inactivity - and thus are unable to provide support for those retired.

In France, worker-to-retiree ratios are available and indicate that whereas in 1970 , three people held a job for every retired person, by 1990 , the ratio had fallen to 2.3 . In 2020 , according to some projections, France's worker to retiree ratio will be even lower, reaching one-to-one! For French companies, this would mean that their contributions to employee's state and occupational pensions, which are already high at $20 \%$ of salary, would have to double to $40 \%$.

Although as already indicated accurate projections of worker to retiree ratios are not generally available, a useful substitute is the ratio of people over age 65 to the employed population; mathematically, these approximate worker-to-retiree ratios may be obtained by multiplying support ratios by the employment rate (the percentage of the working age population that is employed). Table $4 \mathrm{~A}$ gives these ratios for certain OECD countries, assuming, as before, that the employed population is ages 25-59 and that the percentage of that population that is employed is at its average value during 1980-1991 for both 1990 and 2020 (the employment ratios are shown in Table 4B).

\section{Table 4A \\ Worker-to-Retlree-Ratios \\ Selected OECD Countries}

\begin{tabular}{l|c|c} 
& $\mathbf{1 9 9 0}$ & $\mathbf{2 0 2 0}$ \\
\hline Canada & 3.2 & 2.0 \\
Japan & 3.2 & 1.4 \\
United States & 2.9 & 2.1 \\
\hline EU Countries & & \\
France & 2.5 & 1.8 \\
Germany & 2.4 & 1.8 \\
Ireland & 2.0 & 1.5 \\
Italy & 2.1 & 1.4 \\
Netherlands & 2.6 & 1.8 \\
Portugal & 2.5 & 2.1 \\
Spain & 1.9 & 1.5 \\
United Kingdom & 2.2 & 1.9 \\
& & \\
Australia & 3.0 & 2.7 \\
Finland & 3.2 & 1.8 \\
New Zealand & 3.2 & 2.4 \\
Norway & 2.2 & 2.0 \\
Sweden & 2.3 & 1.9 \\
\hline Total of Selected Countries ** & $\mathbf{2 . 6}$ & $\mathbf{1 . 9}$ \\
\hline
\end{tabular}

"Belgium, Denmark, and Luxembourg are not included.

* Arithmetic Average

Source: Support Ratios (Table 3) multiplied by employment rates (Table 48 ). 
By 2020 the estimated worker-to-retiree ratios for most of the countries shown in Table $4 \mathrm{~A}$ will have dropped below 2 to 1 - i. e. there will be fewer than two workers to support each retiree; the ratios in Italy, Japan and Spain will be 1.5 to 1 or under. In countries where retirement occurs before age 65 either as the norm or as the exception to the norm, the problem will be exacerbated.

There is of course a risk that a focus which relies solely on demographics may exaggerate the problem. Wealthy countries with rapidly growing economies may be able to finance increasing social security benefits by reserving a portion of that growth to pay the benefits. On the other hand, few countries, especially the industrialized countries where the demographic problems are most severe, have recently experienced more than nominal economic growth $;^{6}$ in fact, as discussed in the following section, social security financial burdens are already contributing to sluggish growth in many countries.

All things considered, demographic trends have turned strongly against pay-as-you-go social security systems, especially in the developed countries, whose populations are generally aging very rapidly.

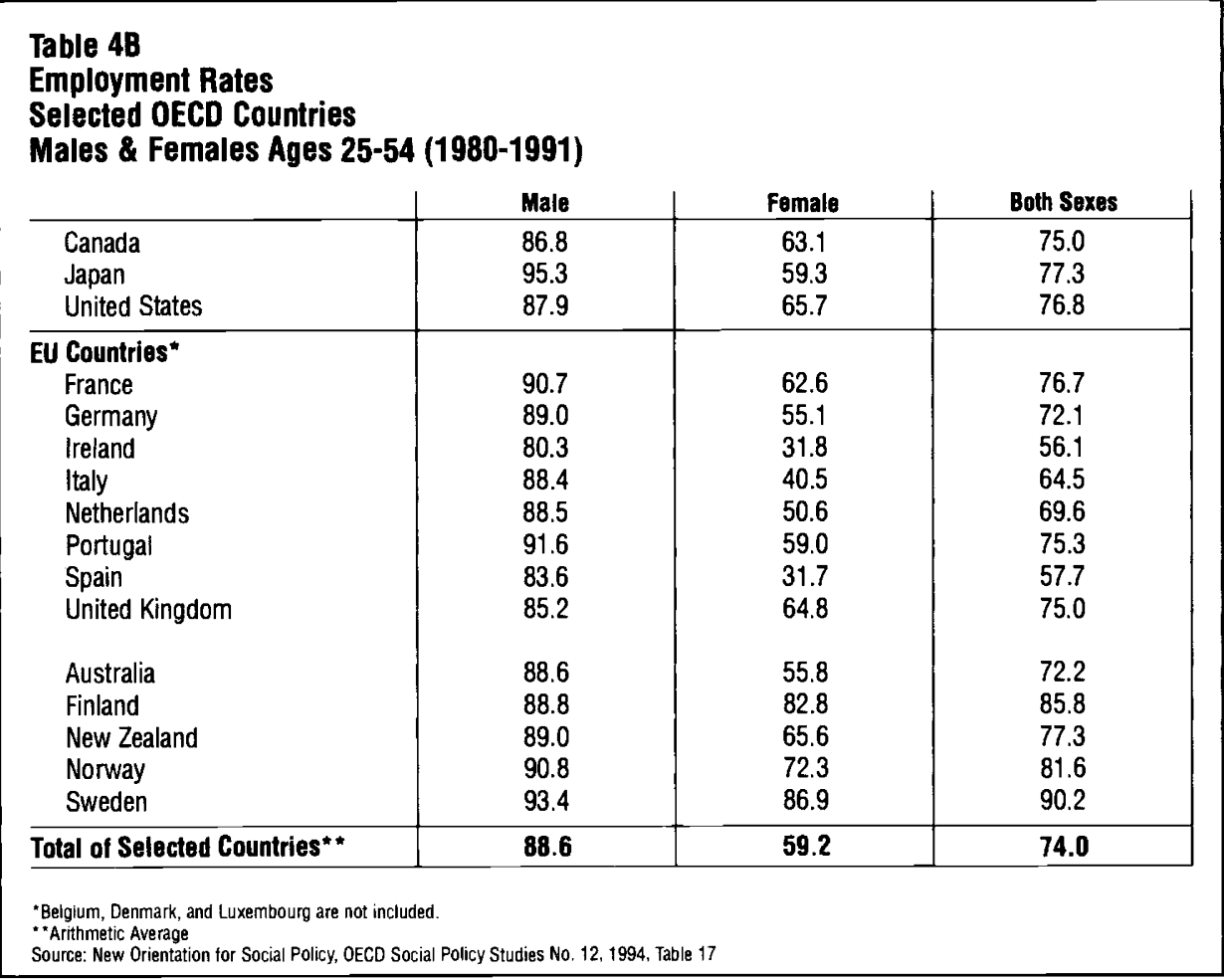
1993.

${ }^{6}$ The average annual real GDP growth for the OECD countries was $2.4 \%$ for the period 1980 to 


\section{Budget deficits and the expansion of social security}

The demographic problems are, of course, compounded when social security retirement benefits are relatively generous, with a high percentage of final average salary provided by the retirement pension. Moreover, an axiom of social security systems seems to be that entitlement programs, however modest initially, are continually expanded thereafter. This has certainly been the case in OECD countries in the period after the Second World War ; public expenditures, and social welfare expenditures in particular, have grown exceptionally rapidly in real terms. Public expenditures as a percent of GDP rose from around $30 \%$ in most European countries in 1960 to $50 \%$ to $60 \%$ in 1990 ; in Sweden, the level is $73 \%$. The growth of the public sector in the U.S. has also been rapid, though somewhat less pronounced : from $28 \%$ in 1960 to $39 \%$ in 1990 .

Social welfare expenditures themselves (public outlays on health services, education, pensions, unemployment benefits and other income maintenance programs, family benefits and welfare) have risen equally rapidly, from $13 \%$ of GDP on average for OECD countries in 1960 to $27 \%$ in 1990 . Beginning in the 1960 s, after a decade or so of high economic growth, a growing number of industrialized countries significantly expanded their social security systems, which in the past had covered only selected segments of the population.? Also, the real levels of social benefits increased very rapidly. In OECD countries, social expenditures grew at an average annual real rate of $7 \%$ to $10 \%$ over the $1960-1975$ period (the United Kingdom being lower, with 5\% growth). Roughly two-thirds of this growth was due to increases in real per capita benefits, with the remainder due to population growth and increases in coverage (e.g., new segments of the workforce).

Continuing into the 1970 s, social expenditures grew rapidly even as the growth in government revenues slowed under the impact of the first oil shock and the subsequent recession. In part for these reasons, government deficits, which had remained moderate until then, rose sharply, contributing to inflationary pressures. The rapid expansion of public sector activities therefore began to be questioned in some countries. In addition, for a number of governments, the expansion of their public sectors was seen as a major reason for a general decline in private initiatives and economic flexibility.

The resulting focus on reducing government expenditures has continued into the 1990s, spurred again by recessionary pressures. In 1993, general government deficits as a percentage of GDP averaged $4.6 \%$ in all OECD countries and $6.9 \%$ in OECD European countries. In the U.S. a level of $3.6 \%$ of GDP was reached while in Italy it reached $10 \%$ and in Greece it was $14.8 \%$. (See Table 5).

Particularly in European countries, reform of public pension plans will almost certainly play a role if budget deficits are to be controlled. Italy's public retirement plans alone now consume over $14 \%$ of GDP and represent $28 \%$ of government expenditures. (See Table 6 ). The deficit in Italy's state pension system ran to 60 trillion lire ( $\$ 35$ billion) in 1993. Britain spends $£ 27$ billion ( $\$ 42$ billion) - more than one-third its entire welfare budget - on state pensions. Almost half of Germany's benefits budget goes for pensions. France's state pension scheme is running a deficit of 20 billion francs ( $\$ 3.6$ billion) and the government calculates that without reform the deficit could reach 300 billion francs by 2010 .

${ }^{7}$ This historical overview is based in part upon "Demographic Change and Public Expenditure", in Demographic Causes and Economic Consequences of Population Aging, United Nations, 1992. 


\begin{tabular}{|c|c|c|c|}
\hline \multicolumn{4}{|c|}{$\begin{array}{l}\text { Table } 5 \\
\text { General government financial balances } \\
\text { OECD Countries } \\
\text { Surplus (+) or deficit (-) as a percentage of nominal GDP }\end{array}$} \\
\hline & 1980 & 1993 & Difference \\
\hline $\begin{array}{l}\text { Canada } \\
\text { Japan } \\
\text { United States }\end{array}$ & $\begin{array}{l}-2.8 \\
-4.4 \\
-1.3\end{array}$ & $\begin{array}{l}-7.0 \\
-1.0 \\
-3.6\end{array}$ & $\begin{array}{r}-4.2 \\
3.4 \\
-2.3\end{array}$ \\
\hline $\begin{array}{l}\text { EU Countries* } \\
\text { Belgium } \\
\text { Denmark } \\
\text { France } \\
\text { Germany } \\
\text { Greece } \\
\text { Ireland } \\
\text { Italy } \\
\text { Netherlands } \\
\text { Portugal } \\
\text { Spain } \\
\text { United Kingdom }\end{array}$ & $\begin{array}{r}-9.2 \\
-3.3 \\
0.0 \\
-2.9 \\
-2.9 \\
-11.4 \\
-8.6 \\
-3.9 \\
5.5 \\
-2.2 \\
-3.4\end{array}$ & $\begin{array}{r}-7.0 \\
-4.3 \\
-6.0 \\
-4.0 \\
-14.8 \\
-3.2 \\
-9.7 \\
-4.1 \\
-8.2 \\
-7.2 \\
-8.2\end{array}$ & $\begin{array}{r}2.2 \\
-1.0 \\
-6.0 \\
-1.1 \\
-11.9 \\
8.2 \\
-1.1 \\
-0.2 \\
-13.7 \\
-5.0 \\
-4.8\end{array}$ \\
\hline Total** EC Countries & -3.8 & -7.0 & -3.1 \\
\hline $\begin{array}{l}\text { Australia } \\
\text { Austria } \\
\text { Finland } \\
\text { Norway } \\
\text { Sweden }\end{array}$ & $\begin{array}{r}-1.5 \\
-1.7 \\
0.3 \\
5.7 \\
-4.0\end{array}$ & $\begin{array}{r}-5.8 \\
-2.9 \\
-9.1 \\
-3.2 \\
-14.7\end{array}$ & $\begin{array}{r}-4.3 \\
-1.2 \\
-9.4 \\
-8.9 \\
-10.7\end{array}$ \\
\hline Total OECD countries & -2.7 & -4.6 & -1.9 \\
\hline
\end{tabular}

European Union (EU) countries are under especially strong pressure to reduce deficits, given their high level and the Maastricht Treaty target for general government deficits. Deficits are to be reduced to a "reference level" of $3 \%$ of GDP (with no fixed target date). The average EU budget deficit in 1993 is estimated at 4.6\% of GDP.

\section{Competitive factors}

Governmental budget deficits, of course, have significant and largely negative macroeconomic impacts. But social security pensions affect the economy in many ways going beyond their impact on government expenditures. Two such related effects, on employment growth and international competitiveness, are discussed in this section.

Concern over competitiveness and employment is especially great in Europe. With the recent recession still being felt, unemployment in Western Europe could be in the range of $12 \%$ in 1994 , exceeding 1985 's postwar high. The economic downturn was related to a number of factors, including high interest rates and the impact of economic recessionary conditions abroad. But structural problems may also be a major factor. Western Europe and the 


\section{Table 6 \\ Social Security Retirement Expenditures \\ As a Percentage of GDP and of Government Outlays \\ EU Countries (1989)}

\begin{tabular}{l|c|c|} 
& GDP & Government Outlays \\
\hline Belgium & 9.50 & 19.27 \\
Denmark & 8.22 & 13.79 \\
France & 11.65 & 23.73 \\
Germany & 10.22 & 22.81 \\
Greece & 12.84 & 26.04 \\
Ireland & 5.88 & 14.52 \\
Italy & 14.34 & 27.95 \\
Luxembourg & 13.23 & n/a \\
Netherlands & 9.22 & 17.14 \\
Portugal & 6.28 & 15.06 \\
Spain & 7.74 & 18.92 \\
United Kingdom & 9.28 & 24.68 \\
\hline Average & $\mathbf{9 . 5 6}$ & $\mathbf{2 0 . 3 1}$ \\
\hline
\end{tabular}

Source: OECD Economic Outiook, Dec. 1993 ed, Table A23

New Orientation for Social Policy, OECD Social Policy Studies No. 12, 1994, Table 1c

U.S. have enjoyed comparable economic growth since the 1960 s, but total employment in the U.S. has almost doubled while during the period the EU's has grown by only $10 \%$.

Notable among the structural problems are high labor costs which are related to high social benefit costs. Average hourly wages are only slightly above those in the U.S. and just below those in Japan, but the additional costs of social benefits give Europe the world's most expensive workforce, adversely impacting international competitiveness. The OECD's semiannual Economic Outlook repeatedly stresses the importance of controlling social spending in improving economic performance.

The generous social benefits were developed in more prosperous times, when Europe was competing primarily with other developed countries. But with increases in free trade and new competitors from Asia, Latin America and Eastern Europe, competition is now more intense. In Poland, for example, labor costs including benefits average $\$ 1.70$ per hour, as compared to roughly $\$ 25$ in Germany. A survey of German companies showed that $30 \%$ are considering plans to shift some production in the next three years, with Eastern Europe heading up the list of destinations. ${ }^{8}$ More than half of Europe's 400 largest companies are expected to shrink their payroll by the end of 1995 .

There seems to be broad agreement within the EU that labor costs must be reduced if Europe is to comprehensively address its unemployment concerns. Indeed, in December 1993, a 184-page plan was put forward by Jacques Delors, the President of the European

8 Peter Gumbel, The Wall Street Journal, December 9, 1993, page A 1. 
Commission, that proposed lowering minimum wages and social welfare labor costs, as well as increasing infrastructure investment.

Of course, in addition to helping finance government social programs, employers in many countries in Western European and elsewhere are a significant direct source of retirement income support through employer-provided retirement benefits. But these same concerns over labor costs and international competitiveness appear to lessen the ability of employers to increase their level of retirement income support to help compensate for reductions in government support. This is particularly the case since employer retirement plans are subject to some of the same demographic pressures as the government systems e.g. aging workforces.

\section{Social trends}

The family has traditionally been one of the major sources of support during retirement. Two generations or so ago in many countries one could expect that the majority of elderly could be supported by children or grandchildren living at home or nearby. But increasingly this is not possible. There are fewer extended families, couples are having fewer children or remaining childless, children and other family members may have moved far away and divorce and remarriage weakens bonds between children and parents. Thus the family may not be available as a source of support if government retirement support is reduced.

Social concerns involving generational equity are also raised by the increasing levels of pay-as-you-go systems. State pensions have resulted not so much in a transfer of resources between rich and poor as between generations. With high ratios of retirement benefits to salaries and with benefits indexed for inflation, the disposable income of retirees in some countries is higher than that for working families with children. With limited government resources, some are questioning whether it is fair to increasingly devote so much of a nation's product to the elderly at the expense of younger generations.

\section{Capital markets and other factors}

While the financing problems and competitive issues are the major factors driving privatization in most countries, other elements are also important. One is the positive impact that may be realized on capital markets. There is ample evidence that private retirement savings and income plans can increase national savings and thereby increase capital formation and contribute to improved productivity. In countries with relatively underdeveloped capital markets, like Chile's ten years ago, privatized pension fund savings have played the major role in developing large, liquid pools of capital and in creating equity markets. Pension fund assets in Chile grew to $\$ 12.4$ billion at the end of 1992 , representing nearly $40 \%$ of that nation's GDP. ${ }^{9}$

Capital market benefits can be important even in highly developed economies. A stated aim of Italy's recent retirement savings initiatives was to help bolster the country's underdeveloped stock market to pave the way for privatization of some government-owned industries. Officials in that country also see pension funds as a market capable of absorbing government debt. Similarly, France's planned shift towards private pensions is expected to provide a significant new source of funds for the stock market and play a part in the government's privatization plans.

\footnotetext{
${ }^{9}$ The privatization of Chile's social security system is described in part 3 of this paper.
} 
Another major reason for privatization is to achieve the increased efficiency and equity the private pension system can provide. In many countries (perhaps especially in developing ones), administrative costs of public systems are high, because of management inefficiencies and excessive staffing. Record-keeping and benefit payment procedures may be poor. There may be major gaps in compliance, with revenue from contributions much less than it should be (e.g., because earnings may be understated). The generosity of public sector pension benefits may vary considerably across various employment categories (as was the case in Chile before the privatization). Private systems and the competitive forces they involve oftentimes spell greater efficiencies.

Finally, there are significant intangible benefits to privatization. In Chile, three times a year, each pension fund participant receives a statement of his or her account value, which for many people contributes greatly to a sense of security and well-being. It can be further argued that greater reliance on private saving for retirement also encourages individual initiative and responsibility, which can have widespread social benefits.

Summing up, the ability of governments to provide retirement income support has been eroded by demographic and budgetary trends. At the same time, in the face of competitive pressures, employers may be less able to provide support and, under the impact of certain social trends, families are less able to provide support as well. Thus individuals will increasingly need to save for their own retirement, as government retirement benefits are reduced or privatized - in the ways discussed in the next two sections.

\section{Social security reform}

The objectives of social security reform are broadly clear: the costs of social programs must be reconciled with demographic trends and limits on public expenditures and taxation. At the same time, steps taken must be politically achievable, consistent with social goals and soundly conceived.

\section{Social security systems}

As a framework for discussion, let us first briefly review the major types of social security systems and the role they play with economies and social structures. Professor Gøsta Esping-Anderson of the European University Institute in Florence has divided welfare states into three broad types: the conservative, liberal and social democratic models. ${ }^{10}$

The conservative model, found in countries such as Germany, Italy and France, is said to be designed to preserve status differentials and to reinforce the role of the worker and the family. Social insurance typically excludes nonworking wives and family benefits are often designed to encourage motherhood. The social security system focuses mainly on employees, funding social insurance benefits through employer and employee contributions.

The liberal model, common in Anglo-Saxon countries such as the U.S., Canada and Australia, also focuses upon the worker and is based upon the safety net approach to welfare. Liberal welfare states offer subsistence benefits only to those whose means fall below minimum levels. This reflects the belief that generous welfare benefits will interfere with the efficient working of labor markets. The private sector, including, of course, in-

${ }^{10}$ Gosta Esping-Anderson, The Three Worlds of Welfare Capitalism, Princeton University Press, Princeton, N.J., 1990. Also see John Willman, "Individual Ways to Coin It", Financial Times, November 3, 1993. 
surance companies, provides additional benefits to those who can purchase them or who receive them from employers.

The third model, which is found in the Scandinavian countries, is the social democratic welfare model, in which all citizens have rights to generous benefits provided by the state using tax revenues. Unlike the conservative model, the ideal is not to maximize dependence upon job and family but rather on the desirability of being independent, with the state taking direct responsibility for caring for children, the aged and the disabled.

Generally speaking, the government pension plans for all three types of welfare states have felt the pressures of deficits and increased costs, but in different ways. Welfare benefits in liberal model states are usually funded out of general tax revenues and therefore have been vulnerable to taxpayer upheavals, in which voters have refused to pay for the cost of a welfare state from which they increasingly opt out.

Similar pressures have emerged in the social democratic welfare states, where benefits are also funded from general revenues. The impact is cushioned because all taxpayers received generous benefits, regardless of income. But the tax rates have tended toward unsustainable levels in countries such as Sweden, leading to the election of governments committed to reducing welfare benefits.

Within countries using the conservative model there is less exposure to taxpayer pressure, since it is largely paid for by payroll taxes affecting employers as well as workers. But as discussed above, concerns over international competitiveness are forcing such countries to consider reforming their systems.

A fourth type of system (not focussed upon by Professor Esping-Anderson) seen particularly in some developing countries (e.g., Malaysia, Singapore, Chile, Sri Lanka, and Tanzania) is the national provident fund model. ${ }^{11}$ This is a mandatory defined contribution plan with contributions typically shared by the employer and employee and usually with no government subsidy (except possibly for guaranteed minimum pensions). Contributions are identified with each member and accumulated, with interest, in an individual account. Benefits are often payable in a lump sum, although in some countries the accumulated funds must be converted into an annuity. Most provident funds are run by the national government ; however, the provident funds of Chile, Argentina and Peru (discussed further below) are run by the private sector.

In the view of Professor Esping-Anderson, the welfare state should be viewed broadly in terms of the state's larger role in managing and organizing the economy, not just narrowly in terms of social amelioration. This viewpoint seems equally appropriate in considering privatization of social programs. Accordingly, the perspective taken in this paper is on privatization's potential impact on economic growth, employment and national wealth, as well as on social welfare.

\section{Solutions}

Solutions to the problems surrounding the financing of social security benefits may be considered to fall into three broad categories: increases in funding, decreases in benefits and privatization.

11 Subramaniam N. Iyer, "Pension Reform in Developing Countries, International Labor Review, Vol. 132, 1993, No. 2. 
Funding can be increased by raising payroll taxes or other taxes, but this is politically difficult and can hamper economic growth; moreover, at some point, increases in tax rates have the effect of reducing economic activity and employment and thereby reducing total tax revenues. Increased funding can also come from general revenues, but unless offset by higher taxes, already high budget deficits will increase; the average government debt in OECD countries jumped from $23 \%$ of GDP in 1979 to $44 \%$ in 1992 . Increased immigration can also help increase funding, but only if the immigrants can be productively employed, and many industrialized countries are having difficulty creating enough jobs for their current population (although this may change as the population ages and fewer young people enter the job market).

Benefits can be reduced - though often only with considerable political difficulty - in many ways, e, g.: directly reducing benefits, reducing cost-of-living increases, means testing of benefits, taxing benefits, or increasing the eligibility age for retirement. ${ }^{12}$ Unlike increasing contributions, this type of solution represents a de facto privatization for people not yet retired, since individuals will be encouraged to increase their retirement savings or seek increases in employer-provided pensions in order to preserve their desired level of retirement income.

All of these steps, and many others, have already been taken in countries around the world. For some countries, e.g. the United States, a combination of increased contributions and decreased benefits may be sufficient to sustain the social security pension system for many years. However, for the reasons discussed in the previous section, for many countries the preferred long term solution will be a shift to the private sector, whether through an explicit privatization, as seen in Chile and the UK, or through a more gradual shift as public programs are progressively deemphasized and incentives supporting private savings are gradually enhanced.

In the case of Europe, it might be noted that a shift to the private sector is consistent with the European Charter of Fundamental Social Rights of Workers (1989). The charter states that every worker in the EU must be able to have resources at retirement affording him or her a decent standard of living. Furthermore, any person who reaches retirement age but does not have a pension or other means of subsistence must be able to receive sufficient resources for his or her retirement. But this does not imply that retirement systems need to be harmonized. The separation between public and private retirement plans is left to each country to define and change as it sees fit. The test is the combined result of both types of pension systems. ${ }^{13}$

The individual retirement savings market is developing even more rapidly than the employer-provided sector, in some countries even before any reductions in social security. Alerted by media coverage of an impending crisis, people are becoming increasingly anxious over the security of their public pension benefits. In France, these concerns have

12 Since people are living longer and healthier lives, increasing retirement ages may be an especially appropriate step; however, it runs counter to the efforts in some economies when early retirement is encouraged to help decrease unemployment and increase job opportunities for young people. EU countries that have been required by the European Court of Justice to equalize social security pension benefit eligibility ages for males and females are raising the female state pension age to that of the male.

${ }_{13}^{13}$ Giovanni Tamburi, "Pensions in Europe, before and after Maastricht", Life Insurance International, July 1992. 
spawned a booming new market for retirement-related insurance. In the U.S., individual annuities have $\$ 60$ billion in assets, ten times the amount ten years ago. In Spain, life insurance and retirement savings premiums have grown at an average annual real rate of $13 \%$ over the period 1985-1992.

Many governments are inrceasing the tax benefits of private retirement saving products (to the extent that their budgets allow additional tax expenditures). In Sweden a new law giving people tax incentives to save for their own retirement went into effect this year (despite a projected budget deficit of $15 \%$ of GDP in 1994). Last year, Germany increased twentyfold the tax deductions for certain savings products. France recently doubled the tax deduction for the popular PEP plans, a medium term savings product.

In this environment and in competition for this emerging private business, strong distribution and administration, along with investment performance, count for much, and these are the strong suits of many insurance companies.

\section{Problems and criticisms}

The resulting shift towards increasing reliance on the private sector has been criticized on a number of grounds. Perhaps the most important criticism is that privatized plans may not provide appropriate retirement benefits. Three design features can help minimize that risk. First, contributions to a retirement plan can be made mandatory; if the contribution level is the same as for the government system, there would be no increased cost to employees or employers. Second, annuitization of the accumulated funds can also be made mandatory upon retirement, so that retirees do not outlive their assets. And finally, for those whose means or circumstances do not permit sufficient contributions to ensure an adequate pension, the state system can provide a basic minimum benefit.

A related objection is that fixed levels of annuity benefits do not themselves protect against inflation. This criticism is also made of employer-provided pensions, which are generally not indexed for inflation. However, if this is considered a serious problem (as it was in Chile, which has had significant levels of inflation), then indexed annuities could be used, provided the government or other lenders make available assets with returns linked to inflation (both Chile and the UK issue inflation-indexed bonds). Of course, the preferred solution is to reduce inflation. ${ }^{14}$

Doubts have been expressed about the capacity of privatized systems, such as Peru's, to cover people working in the informal sector (about half of Peru's population) ${ }^{15}$ It is, in fact, difficult to see how the informally employed could afford to contribute to a private pension fund. However, this is a problem for the government system as well and a possible solution (short of eliminating the need for informal employment) would appear to be a universal minimum benefit payable to individuals regardless of the level of contributions made to the system. Of course, any such minimum benefits would have to be established after taking into account the additional costs involved.

In countries where capital markets lack maturity, e.g., in Eastern Europe, adopting an almost fully privatized system such as Chile's would be difficult to accomplish quickly. It has

\footnotetext{
14 Some economists believe that indexing for inflation can in itself help to perpetuate inflation. In reforming its economy, Argentina has prohibited indexing for inflation in all forms, perhaps for this reason.
}

${ }^{15}$ See "Peru", International Labor Review, Vol. 132, No. 4, 1993, page 437. 
been agreed by many that private retirement funds would be highly desirable in Eastern Europe to speed up the development of a domestic capital market and to aid in privatizing state-owned industries. On the other hand, because the capacity of undeveloped markets to absorb capital will not initially be great, a gradual transition may be advisable.

Similarly, a transition to private retirement funds should be made cautiously where the. economy lacks stability. If inflation is high, it will likely not be clear how investment returns will fare compared to inflation. In Chile the social security changes were made in conjunction with a comprehensive package of monetarist policies for the economy as a whole.

It has been observed that private retirement plans are not completely immune to demographic pressures. As a population ages, so does the typical corporation's work force, increasing the funding cost, with declining industries likely to be the most affected. All of this is certainly true. But advance funding of employer plans mitigates the pressures and, arguably, individual pensions are largely immune to demographic pressures. ${ }^{16}$

Privatizing government pensions as in Chile may do little to reduce public expenditures in the short run, as those who are already retired will still receive their state pensions and the past service of those not yet retired needs to be funded. Moreover, if contributions previously made to the state system are transferred to private funds, the financial strains on the state pension system will actually increase in the short run. This is a significant difficulty, but one which Chile, with its very high economic growth, has successfully managed. ${ }^{17}$

Recently, there have been two incidents that have suggested to some that private pensions need to be closely regulated. Some have referred to the Maxwell case - where $£ 450$ million was alleged to have been stolen from the pension funds of the late Robert Maxwell - as an argument that the draft EU Pension Funds Directive (which would provide freedoms of cross-border investment of pension fund assets and of pension fund management) should be made more restrictive. In the UK there are allegations that sales agents have been encouraging the wrong people to buy personal pension plans.

Finally, "market failure" theories have sometimes been used as an argument against private pensions and in favor of social insurance. ${ }^{18}$ For example, the private pension market could be said to be inefficient if there were significantly greater economies of scale from having one single provider of annuities (such as the government), or if for some other reason the private market was not effective in providing retirement income. But in fact, most experts believe that private market failure is not a significant concern for private pensions and that state failures are at least as much a cause for concern.

\section{Privatization and reform initiatives}

This section provides an overview of privatization initiatives in five countries - Chile,

${ }^{16}$ However, the annuity benefit that a given level of retirement savings can purchase will generally decrease as life expectancies increase.

${ }^{17}$ Chile was aided in making this transition by budget surpluses it was running in the early $1980 \mathrm{~s}$.

${ }^{18}$ For a discussion, see Jerry R. Green, “Demographics, Market Failure, and Social Security”, in Social Security and Private Pensions, Susan M. Wachter, ed., Lexington Books, Lexington, Mass., 1988. This book is the proceedings of a 1987 conference on "Social Security and Private Pensions: Providing for Retirement in the Twenty-first Century", sponsored by the University of Pennsylvania and funded by Metropolitan Life. MetLife's CEO at the time, John Creedon, and current CEO, Harry Kamen, were both involved in establishing the conference, which was attended by one hundred invited government, academic and business leaders. 
Peru, Mexico, Italy and Japan - and of the concurrent trends towards private saving for retirement. Several other countries are briefly discussed in a final section.

\section{Chile}

Chile privatized its social security system in 1981 and it has proven so effective that experts from many countries have travelled to Chile to study the operation of its program. The privatization is especially noteworthy given that Chile's social security system was initiated in 1924 and was the first in the Americas.

During the years before 1981, Chile's social security system developed a number of serious problems. ${ }^{19}$ With the gradual aging of the Chilean population, the ratio of contributors to beneficiaries fell sharply from 8 to 1 in 1960 to 2 to 1 in 1980 . The system was considered by many to be inequitable, with different systems for different occupational groups, some receiving much more generous benefits than others who received inadequate benefits. Administration was insufficient and service was poor. Noncompliance was widespread - lax supervision permitted employers and employees to underreport wages until five years before retirement, at which point the employer would boost reported wages (pension benefits were a function of earnings in these last five years). And finally, for all these reasons, the system developed large deficits which, by 1980 , required $28 \%$ of the entire system's cost to fund.

The main feature of the new system, which began operations on May 1, 1981, is a "defined contribution" private retirement plan (i.e. one in which the contributions and not the benefits are specified) based upon mandatory contributions of $10 \%$ of earnings (up to a salary cap which was unchanged from the prior system), withheld by the employer. The employee may also voluntarily contribute up to another $20 \%$ of his or her earnings. Both the mandatory and voluntary contributions are allowed from pre-tax earnings.

When the system began, individuals were given the option of remaining in the old system or transferring to the new one, and over $90 \%$ did transfer. ${ }^{20}$ Participation in the new system was made mandatory for new entrants.

Contributions are made to private pension fund managers referred to as "Administradoras de Fondos de Pensiones" (administrators of pension funds or AFPs). Individuals can freely choose their AFP and change AFPs up to four times a year. The AFPs invest the funds after deducting an administration charge.

Almost all AFP investments (except for stocks) are made in securities whose principal and interest are expressed in a Chilean form of currency called "Unidad de Fomento" (UF), which is indexed for inflation. The value of the pension funds and the benefits flowing from them are also expressed in UFs, so that participants are protected against inflation both before and after retirement.

Individuals also pay an additional percentage of their salary (about 3 to $3.5 \%$ ) to the AFP for disability and survivor insurance, administrative and sales expenses, and profit. The AFP is required to purchase the disability and survivor insurance from an insurance company.

${ }^{19}$ Much of the discussion in this section is from Robert J. Myers, "Chile's Social Security Reform, After Ten Years", Benefits Quarterly, Third Quarter 1992. Also, see Addendum on page 102 of Benefits Quarterly, First Quarter 1993.

${ }^{20}$ Chileans may also opt out of the government health plan for a private plan. 
The system is expected to provide pensions of about $70 \%$ of final salary. Until the new system matures, these benefits cannot be entirely provided by funds from AFPs. But in the interim, the government transfers an amount into each individual's pension fund that recognizes service under the old system. Minimum pension guarantees are also provided by the government in the event that an AFP pension benefit does not exceed a prescribed minimum.

All AFP participants can retire when they please, provided their pension fund has accumulated to a level that can provide retirement income equal to $70 \%$ of final pay, but in any event can retire at age 60 for women and age 65 for men. Upon retirement, the individual has the option of using his or her funds to purchase a life annuity from an insurance company or to obtain a series of scheduled withdrawals directly from the AFP. About twothirds of retirees have chosen the life annuity option. In either case, benefits must also be provided for surviving dependents.

The new system has been very successful and popular with employees. AFP participants have earned high real rates of interest on their funds (an average annual real rate of $13 \%$ through 1990) and some people have done so well with their AFPs that they have been able to retire early.

The assets of the AFPs have grown rapidly, to $\$ 12.5$ billion at the end of 1992 , about $40 \%$ of Chile's GDP. Chile's capital markets have benefitted, and Chile now has a well developed stock market. The pension savings satisfy so much of Chile's need for capital that the country is largely insulated from the fickleness of international investors. Much of the vibrancy of the Chilean private sector has been attributed to its ability to tap this stable, reasonably priced, longterm money.

Finally, the privatization has greatly stimulated the growth of Chile's life insurance industry. Life and annuity premiums have grown at a $15 \%$ real rate since the privatization, and the percentage that these premiums are of Chile's GDP increased from $0.46 \%$ in 1981 to $1.8 \%$ in 1992 .

\section{Peru}

Peru's reformed system, which is similar to Chile's, began operating in June 1993. The government system still maintained by the government is in poor shape, reflected by such factors as the enormous national debt, systematic evasion of contributions by employers, and excessive administrative costs. Only one-third of the labor force is covered by the government system and with inflation pension benefits have become drastically reduced in real terms. It is also hoped that the new private pension funds will stimulate the investment Peru needs for its program to privatize government-owned industries.

Much as in Chile, individuals can contribute up to $10 \%$ of their salaries on a pretax basis to an AFP, which buys life and disability policies from insurance companies. Employees who switch to an AFP are given a $13 \%$ pay raise to compensate for the increase in contributions and the cessation of those formerly paid by employers. Annuities can be received either from the AFP or an insurance company.

Employees are free to join the AFP of their choice and to later switch between AFPs. Transfer from the government system to an AFP is not mandatory, even for new entrants (although there is still some uncertainty on the treatment of new entrants). Workers joining an AFP receive a cash voucher for their past contributions to the government system. 
Workers may also rejoin the government system, although they will then forego their $13 \%$ pay increase and the cash voucher.

To date the privatized system seems to have been successful. Projections are that by the end of 1994 , nearly 850,000 people out of a work force of nearly 8 million will have contributed about $\$ 400$ million to the AFPs. In November 1993, only a few months after the system started, 530,000 had already joined.

\section{Mexico}

Mexico intends to take a more gradual approach to privatization than Chile or Peru by creating a private pension fund system that will operate indefinitely alongside the state system. Employers make mandatory contributions to the new system on behalf of employees, but employers and employees also continue to contribute to social security at the same level as before.

Starting in May 1992, employers were required to contribute $2 \%$ of employees' wages to a fund selected by the employee, known as a SAR (Sistema de Ahorro para el Retiro). Employees also have the right to make additional payments into their SAR account, tax deductible up to $2 \%$ of salary. Upon retirement, the employee may purchase a life annuity with his or her accumulated funds or take the funds in a lump sum. Annuities will be tax exempt up to nine times the minimum wage; likewise, lump sums are tax free up to the equivalent single premium value.

Currently, the funds can only be invested in accounts administered by banks; the banks in turn are required to invest the funds with the Mexican Central Bank. It had originally been planned that starting in January 1993, insurance companies and brokerage firms could also administer, and perhaps invest, SAR funds, but the enabling regulations have not yet been passed.

Like Chile's AFPs, the SARs are designed to promote savings and investment and take some of the burden off the government pension system. Mexico's population is still young - only $4 \%$ are over age 65 - but it is aging fairly rapidly. In 1990, for the first time, the age group 0-4 years was smaller than the age group 5-9 years.

The system is also intended to increase retirement income - state retirement benefits in the past have been eroded by inflation, since payments are based on final average salary of the last five years unindexed for inflation. However, with the recent decline in Mexico's inflation rate, real benefits have increased significantly. In combination with the demographic trends, this has led to concern over the government's ability to finance the system and there has been a publicity campaign to encourage individual savings.

However, the impact of the new system will be limited by the relatively small size of the contributions. At present rates, total pension assets are expected to grow to only $\$ 10.5$ billion by the year 2000. That compares to the Mexican stock market's current capitalization of $\$ 125$ billion. But some project that the contribution rate will eventually be increased to $10 \%$, offset by corresponding cuts in social security.

An annuity market is also developing in Mexico that allows individuals to save for their retirement in a tax-favored way. Legislation recently passed made premiums for deferred annuities sold by insurance companies tax deductible up to an annual limit of about $\$ 12,000$. The payments (which can be taken as an annuity or in a lump sum) are taxable when received. This market has so far been slow to develop, in part because banks also have tax-deferred accounts. 
Except for mandatory termination indemnities and seniority premiums (a small additional lump sum benefit), employer-provided retirement benefits are uncommon in Mexico.

Italy

Italy's conservative model pension system is one of the most generous - and most expensive - in the world. Public pension expenditures for the aged in Italy consume over $15 \%$ of Italy's GDP and the system operates with huge deficits. In Italy's 1993 budget, the government was required to pay 60 trillion lire ( $\$ 35$ billion) to bridge the gap between contributions and payments. Public pensions are thus a major contributor to the government's large budget deficits. The total cost (employer and employee) of all social security benefits exceeds $50 \%$ of payroll.

Moreover, Italy's demographic trends - in this regard - are among Europe's most unfavorable: Italy's fertility rate is 1.3 , among the lowest in the world, its life expectancy is among the longest and its population, already old, is aging rapidly.

It is widely recognized in Italy that social security reform is needed, but (in part because of the views of unions and government employees) efforts to pass comprehensive reform legislation often failed in the past. But significant reforms were enacted in 1992. Retirement ages were gradually increased from $60 / 55$ (M/F) to 65/60 in 2003 and the earnings period used to calculate pensions were gradually increased from the last five years to the last ten years. Retirement benefits are also being harmonized to eliminate excessive privileges enjoyed by public sector employees, who were able to receive pensions after short periods of work regardless of age; the reforms will gradually require 35 years of covered employment, the same as for private sector employees.

In April 1993, a much-awaited complementary bill was passed to develop private sector retirement plans. The government seemed anxious to encourage the development of private plans not only to relieve the pressure on social security, but also to develop the Italian capital market. Currently, less than $5 \%$ of the population has a private pension plan. ${ }^{21}$

The law provides incentives to employers, trade unions and individuals to establish pension schemes to supplement social security. However, many observers were disappointed with the limitations placed on the incentives. Total pre-tax contributions are limited to $10 \%$ of pay. Employee contributions to pension funds are deductible up to the same limits as apply to insurance premiums: the lower of $27 \%$ of salary or 3 million lire $(\$ 1.775)$. In addition, $15 \%$ of the contribution is withheld by the government as an "advance tax". The benefits, when paid, are taxable and the $15 \%$ withholding will then be applied as a credit.

Employer-sponsored schemes must be defined contribution plans and at least $50 \%$ of the benefits must be paid as an annuity upon retirement. The annuities must be provided by an insurance company. Insurance companies are also the only financial intermediaries entitled to guarantee a minimum return on investments.

The private plan must be established as a separate legal entity. Employers can directly administer pension plans for their employees or the plan may be administered by an insurance company, bank or certain other financial institutions.

${ }^{21}$ Lucia Vitali, "The debate on the private-public mix in pension systems: the European scenary and the Italian case", Geneva Association, November 1993. 
If an employer has a pension plan, the employer is required to fund the mandatory termination indemnity for new employees through the pension plan as part of the maximum $10 \%$ contribution. Termination indemnities (lump sum payments made when an employee leaves employment) accrue at $7.6 \%$ of salary per year. Employers may also fund termination indemnities for other employees. Thus, in a sense, the new law is not strictly a pension law but is really a law intended to encourage employers to fund their termination indemnities $^{22}$ (which previously were usually accounted for through book reserves, although some employers purchased insurance contracts).

The current private pension market is limited because legislation enacted in 1988 abolished the cap on contributions and the earnings base, keeping the ratio of retirement benefits to salary high even for higher paid employees. Moreover, termination indemnities act as a type of lump sum pension benefits. Unfunded termination indemnities were used by companies as a major source of low cost financing.

It remains to be seen how successful the recent legislation will be in developing the market. The tax incentives for pension fund contributions, particularly by employees, are not generous, and, in fact, as mentioned, the government is withholding a $15 \%$ tax. The difficulty is that, with an almost crippling budget deficit, Italy cannot easily reduce tax revenues.

Because it did not reduce or privatize its pension benefits sooner, Italy now faces a difficult choice : its large budget deficits, while caused in good part by social security pensions, may inhibit the government from providing the tax expenditures that appear necessary to privatize pensions.

\section{Japan}

Japan, as mentioned previously, has a population that, while not yet very old ( $12 \%$ are over age 65), is aging quite rapidly, faster than any other industrialized country. By 2020 , its percentage of population over age 65 is projected to double, to $24 \%$, overtaking Sweden's as the world's oldest population. Not only are Japanese living longer - in 1993 the average life span was 76.1 for men and 82.2 for women, both the longest for any country in the world - but Japanese women are bearing an average of 1.5 children, well below the replacement level.

The government, employers and the general population have been very much concerned with the consequences of this rapid aging, which is likely to be especially severe because, even after the 1985 reforms (discussed below), the social security system remains very generous and because Japanese companies have a tradition of early retirement, as early as age 55 .

Recognizing the looming financing crisis - the combined employer/employee contribution rate for the earnings related benefit was projected to increase from $10.6 \%$ in 1985 to $38.8 \%$ by the year 2030 - the government enacted reforms to the public pension system in 1985. The system was substantially restructured in perhaps the most radical reform of public retirement provisions among OECD countries in the 1980s. The reformed system is generally a liberal model system.

\footnotetext{
${ }^{22}$ Bruce F. Spencer, IBIS Review, February 1994, page 8.
} 
The reform had three basic features: unification, universal benefits and reduction in benefit level. The reform unified the three main schemes in the prereform system: the Employees Pension Insurance (EPI), the National Pension Schemes (NPS), and the Mutual Aid Association (MAA). The EPI was an earnings-related scheme covering employees of private sector firms with more than five employees. The NPS was a flat-rate benefit covering the self-employed and workers in agriculture, forestry, fishing and smaller companies. The MAAs covered public employees and a few other groups of employees.

In the reformed system, the NPS has become a flat-rate basic universal benefit paid to all elderly. The MAA and EPI were combined into a single earnings related program; however, the benefit was reduced from $1 \%$ to $0.75 \%$ of final average salary for each year of service. The NPS is funded by a combination of employer and employee contributions and general revenues. The EPI is funded by contributions of $14.5 \%$ of salary paid equally by employees and employers.

Despite the reforms, the system remains generous. The NPS benefit is 702,000 yen or about $\$ 7,000$ a year (1991), with automatic indexing for inflation, and combined with EPI the benefits provide an average of about $68 \%$ of pre-retirement income. The eligibility age for NPS benefits is 65 and for the EPI it is 60 for males and 57 for females (gradually being increased to 60 ).

Projections in 1993 showed that, despite the reforms, if the system in unchanged the employer/employee contributions would need to increase from the current $14.5 \%$ to $35 \%$ in 2025. In 1993, the government proposed gradually increasing the age at which full EPI retirement benefits are received to 65 . Even with the proposed reform, the contribution rate may grow to 27 to $28 \%$. Further legislation is expected to be proposed.

Despite generous social security benefits, Japan also has fairly well developed employer-provided retirement income plans. There are three types: severance plans, pension plans and Employees' Pension Funds (EPFs). All three are tax-qualified. The severance plans provide lump sum termination benefits and are not funded. The retirement income plans, which must be funded, are structured to provide benefits as annuities, although employees may, and usually do, elect to receive lump sums.

EPFs are reserved for employer plans contracted out of the EPI - since, as in Great Britain, Japanese employers may do so. However, the option is only available to employers with more than 500 employees or multiemployer groups within the same industry with more than 3,000 employees. Plans choosing to contract out must provide funded benefits at least $30 \%$ higher than those paid by EPI.

\section{Other countries}

Elsewhere in Europe, Switzerland and the UK have so far made noticeable progress toward privatizing pensions. A 1985 law forced Swiss companies to provide employees with pension funds, which now total $\$ 145$ billion.

In Britain, where corporate funds are well established, the government has focused on reducing the state role in retirement income provision and increasing the role of individual retirement savings. The worker to retiree ratio is expected to decrease to 2,0 in 2030 from 3.5 currently, and government pensions are already the single largest item of government expenditure. 
Beginning in 1988, people were allowed to contract out of the supplementary state earnings-related pension scheme (SERPS) by establishing personal pension plans, to which the employee's SERPS contributions would be redirected. Personal pension plans are deferred annuities offered by insurance companies, banks, building societies and unit trusts (mutual funds). Contributions can be made out of pre-tax earnings (up to a limit) and accumulate tax-free. Pension income is taxed as earned income, but when benefits begin, a lump sum of up to $25 \%$ may be taken tax-free. Employees are also allowed to opt out of employer-provided pensions (which are widespread in the UK and in most cases replace SERPS) in favor of personal pensions.

The government has also taken steps to directly reduce state pension expenditures, including decreasing the percentage of pre-retirement income provided by SERPS from $25 \%$ to $20 \%$ and indexing the flat rate basic pension to the inflation rate rather than to the increase in earnings (which usually increase at a greater rate than inflation). With a continued increase in real earnings, the basic pension benefit is projected to decrease to $6 \%$ of average income in 2040 from its current level of about $20 \%$.

Efforts have been less pronounced in Spain. Four years ago, the Spanish government offered tax advantages to companies that would fund their pension schemes instead of using book reserves. But few employers moved to fund their plans because the tax benefits were not generous enough and also because - in the eyes of the employers - the law gave employees and their trade unions too much control over the investment fund. In October 1992, the government introduced a bill to force companies to fund their pensions, but the bill died at a time when reducing Spain's $22 \%$ rate of unemployment took priority. The Spanish government is now resubmitting a proposal to abolish book reserves. If enacted, all pension promises would have to be funded either through an external pension fund manager or an insurance contract.

At the same time, the future of the Social Security System in Spain is under active discussion by the government, employees and unions. A recent warning by Spain's Minister of the Economy that Spain will be unable to guarantee the government retirement benefits to Spaniards currently in their forties caused concern and produced reports that a major reform of the system is imminent. In part because of Spain's high unemployment, workerto-retiree ratios were only 1.9 to 1 in 1993, down from 3.4 in 1977, and projections for 2020 show the ratio dropping to as low as 0.5 to 1 ! The Economy Minister has called for a law providing incentives for private pension plans by 1995 to help replace the public plan.

In France, as mentioned previously, there are projections of a one-to-one worker to retiree ratio in 2020 and the outlook for the social security system is troublesome. The social security system provides retired workers with a pension of $50 \%$ of their average wages for their ten best years, adjusted for inflation. Both contributions and benefits are based on annual earnings capped at about the equivalent of $\$ 23,000$. There is also a noncontributory minimum pension financed from general taxation.

The French system also includes mandatory employer schemes. In combination, the two pension benefits replace a high percentage of salary, in the range of $70 \%$ to $90 \%$. In some cases, the mandatory system provides employees with more income when retired than when working.

The government pension system had an estimated deficit of 40.1 billion francs in 1993 . Reform legislation passed in 1993 increased the required contribution period from 37.5 
years to 40 years (indirectly raising retirement ages) and related pension benefits to a person's 25 best years, rather than ten. These changes are modest and are viewed as stop-gaps.

A more comprehensive reform would involve creating a system of private funds that would supplement social security and would help further develop the French capital markets. The government has indicated plans to present a plan in 1994 to introduce funded private pensions. Insurers will likely have opportunities to provide pension products to this new market.

Already, for many years, French insurance companies have been able to sell capitalization contracts that are pure savings policies with no protection element that can be used to save for retirement. If held for more than eight years, the proceeds are free of $\operatorname{tax}$. The sales for these products have been quite strong.

Even in the country in which Social Security began, Germany, the government pension scheme was reformed in 1992, so as to reduce expenditures. The major changes were: (i) gradually increasing the age from 63 to 65 at which full retirement benefits can be received with 35 years of coverage from 63 to 65 , (ii) indexing pensions in course of payment to increases in net pay (after income and social security taxes) rather than gross pay, and (iii) introducing changes into the formula for computing initial benefits. As a result of the reforms, pensions are already estimated to be $20 \%$ lower than they otherwise would have been. ${ }^{23}$

Despite these reforms - and despite Germany's wealth - the German social security system is under considerable strain. ${ }^{24}$ A third of Germany's GDP now goes for social spending, and social insurance contributions for 1994 are a projected $40.2 \%$ of gross pay (employer and employee combined), up from $26.5 \%$ in 1970 , and as discussed previously, the business community is very much concerned about the impact on international competitiveness. The population of the unified Germany is already relatively old, with $14.6 \%$ over 65 , and is aging, with $19.1 \%$ over age 65 projected for 2020 . Unification with the slightly younger Eastern Germany has added 17 million people - potential new social security participants who are entitled to full benefits but have only now begun contributing. ${ }^{25}$

Fortunately, Germany already has a very well developed retirement savings market that can assume a greater role as the government system is gradually reduced ${ }^{26}$ Germany's life insurance and retirement savings market is the world's fourth largest and most employees are members of employer-provided plans. Most employer plans are financed through book reserves, but the Pension Funds Directive and any future EU pensions legislation may encourage prefunded plans.

In the Americas, Argentina decided to privatize its social security pension system along Chilean lines in September 1993. Beginning in May 1994, Argentineans have the option of 10.

${ }^{23}$ Professor Jens Alber of Konstanz University, as quoted in Financial Times, March 8, 1994, page

${ }^{24}$ Increasing the strain, the system was expanded to include nursing care for the aged as a result of a cross-party compromise agreed to in March 1994.

${ }^{25}$ The 1993 subsidy for social insurance programs in the eastern states is about $\$ 143$ billion, of which about $\$ 97$ billion is for retirement pensions. Germany.

${ }^{26}$ However, currently there are almost no employer-provided retirement plans in eastern 
directing $11 \%$ of their salary withheld for social security to either the government system or a newly instituted private system. As this is written, it is expected that at least half of the covered individuals will choose the private option (most of whom will likely be under age 45). Employers will continue to contribute $16 \%$ to the state system, which will continue to provide a basic minimum benefit and to provide benefits already earned under the state system. Many international insurance companies and banks have set up pension funds and affiliated insurance companies to take advantage of the privatization which is proceeding under a dramatically

improved Argentine economy.

Columbia is also in the process of privatizing its social security system, again along the Chilean model. In Brazil, still plagued by very high inflation, the Congress is reviewing a proposal for reform of social security system, which would include individual capitalization plans for higher paid employees. Because of already high budget deficits, the government has been having severe difficulty providing increases to compensate for inflation for pension benefits in the course of payment, as required by law. ${ }^{27}$ Employer-provided pensions are not yet common in Brazil, but this benefit is becoming more widespread because of relatively low social security benefits.

In Canada, concerns are being expressed over the cost of its generous liberal model social welfare system; social security, health care and education make up $60 \%$ of total government outlays. Canada's government retirement income system is two-tiered: a flatrate universal Old Age Security (OAS) benefit and an earnings-related benefit from the Canada/Quebec Pension Plan (C/QPP). The OAS is funded out of general tax revenues and the C/QPP is funded by employer/employee payroll taxes, currently $5.2 \%$ in total. Together the two benefits provide $39 \%$ of preretirement earnings for an average wage-earner.

The C/QPP plan was introduced only in 1967, the last year of Canada's baby boom (which was even more pronounced than in the U.S.). ${ }^{28}$ With the subsequent demographic and economic changes, the original projections for the cost of the plan have since proven optimistic and current projections indicate that the combined C/QPP contribution rate will have to rise to $13.3 \%$. Canadian taxes are already high ( $40 \%$ of GDP in total, up from $31 \%$ in 1981) and so reductions in benefits seem likely. ${ }^{29}$ Canada's well-developed retirement savings markets will be able to take advantage of gradual privatizations as they occur.

Finally, in the world's most populous country, China, a comprehensive social security system is still being developed. Typically, benefits in China have been provided by systems set up by state-owned enterprises or city and county governments. For at least the past dozen years, China has sponsored a series of visits by foreign advisors with the aim of setting up a national social security system. A communique issued in November 1993 proposed establishing a "multi-layered social security system", including benefits based upon individual accounts, supplemented with commercial insurance. ${ }^{30}$

${ }^{27}$ A a result of a court order, in January 1992 the Brazilian government granted social security beneficiaries a $147 \%$ benefit increase; the increase is estimated to cost $\$ 11$ billion in the first year.

${ }^{28}$ Robert L. Brown, "Worldwide Social Security Programs", Record of the Society of Actuaries, Vol. 18, page 2165 .

${ }^{29}$ In a November 1993 report, the Canadian Institute of Actuaries has proposed four alternative reforms for the C/QPP plan, three of which involve benefit reductions.

30 IBIS Briefing Service, December 1993, page 8. 
At the same time, in a somewhat conflicting trend, the government is encouraging local governments to experiment with methods of providing retirement income. For example, Shenzen, in the Guangdong province, is establishing a funded social security system with individual retirement accounts. Coverage extends beyond state-sector companies to include employees in private and joint-venture enterprises. ${ }^{31}$

The Chinese have traditionally looked to their family for support during retirement. However, the rigorous enforcement on China's one-child family policy may put an end to traditional notions of family care in China, with responsibility shifting to individuals to look after their own needs as they get older rather than relying on the younger generation. The day has not yet come when every Chinese peasant has his or her own individual retirement savings plan, but with the country's rapid development, that day - with its huge implications for the private sector funding vehicles that would be required - may not be too far away.

\section{Conclusion}

Powerful demographic, fiscal, economic and social forces are placing increasingly severe strains on social security systems. It will not be easy to find ways of improving the financing of the systems, or more generally, to find feasible and equitable ways of providing for secure retirement incomes; there is much yet to be learned about which approaches will maximize social welfare. Each country will have to find its own types of solutions to the problems it faces.

But the trend, worldwide in scope - affecting both developed and less developed areas and countries as diverse as Canada and China - is increasingly and inevitably pointing toward privatization of government social security systems and increased reliance on individual savings. The emerging opportunities - and challenges - for insurance companies and other financial services institutions will be huge.

The correlative question is what types of institutions and types of companies will be the most successful in developing retirement savings alternatives. Distribution approaches will vary, but their role will be critical; it is far from clear that traditional systems will be the most successful. Competition will be intense and distribution must be cost effective - but full service systems will probably be the most successful.

Worksite marketing - in which agents or brokers sell retirement savings or life insurance products directly to employees at their place of work, with the cooperation of employers - is one example of a non-traditional distribution method that may produce the desired effects. Generally employers do not contribute to the cost of these products but often arrange for payment through payroll deduction. Worksite marketing is cost effective and as employers de-emphasize their retirement plans and governments reduce theirs, it will be a logical way to market retirement savings products.

From a still broader perspective, the privatization trend is linked to two other powerful global trends affecting insurance: Bancassurance and the increasing focus of insurance products on asset accumulation rather than protection. To take advantage of these trends, insurance companies will generally need to develop and sell products with a strong savings component. Insurance companies may have an advantage over banks and other financial institutions in marketing retirement savings products, because of their strong distribution

31 Social Security Bulletin, Spring 1993, page 94. 
systems and because of their reputation for investing for the long term and with long term guarantees. But to the extent that people also tend to turn to banks for savings and other services, the growth of the retirement savings market may reinforce the growing ties between banks and insurance companies.

The privatization trend also implies that even some life insurance markets that are usually considered mature - such as some European ones - may yet prove to be emerging markets for retirement savings products.

In sum, it is safe to say - echoing the management guru Peter Drucker - that the retirement savings market is one of the great new markets of the future. ${ }^{32}$ Insurance companies that focus efficiently and effectively on these new markets as they develop around the world should do well.

32 Peter F. Drucker, Wall Street Journal, April 9, 1992, page A 14. 